University at Albany, State University of New York

Scholars Archive

$12-2010$

\title{
Apartheid on Trial: South West Africa and the International Court of Justice, 1960-1966
}

Ryan Irwin

University at Albany, State University of New York, rirwin@albany.edu

Follow this and additional works at: https://scholarsarchive.library.albany.edu/history_fac_scholar

Part of the African History Commons

\section{Recommended Citation}

Irwin, Ryan, "Apartheid on Trial: South West Africa and the International Court of Justice, 1960-1966"

(2010). History Faculty Scholarship. 21.

https://scholarsarchive.library.albany.edu/history_fac_scholar/21

This Article is brought to you for free and open access by the History at Scholars Archive. It has been accepted for inclusion in History Faculty Scholarship by an authorized administrator of Scholars Archive. For more information, please contact scholarsarchive@albany.edu. 


\section{RYAN M. IRWIN}

Apartheid on Trial: South West Africa and the International Court of Justice, 1960-1966

Harold Taswell was not a happy man in the summer of 1965 . As South Africa's ambassador to the United States, he held one of the most important and prestigious positions in the Republic's Office of Foreign Affairs. However, things were not going well. In August, he presented a less-thansubtle report to his superiors in Pretoria: 'Could Paul Kruger have avoided war with England and yet retained the integrity of the Republic? Will we be able to avoid an armed clash with the United States-or an armed clash with the United Nations strongly backed by the United States-and still retain our integrity? There is a parallel between the period preceding the Anglo-Boer War and conditions prevailing today. The situation is equally dangerous.'

He went on to outline the nature of the threats facing South Africa. '[P]owerful forces' in Washington were out to 'goad and provoke [South Africa] into taking some action which would give America a face saving excuse for applying sanctions against us, for breaking off diplomatic relations and finally for armed intervention.' Framing President Lyndon Johnson as a 'calculating yet quick tempered, 
impetuous man,' Taswell further lamented that the American President was so committed to racial integration that he was 'push[ing] aside all those who stand in his way . . [even] his own Whites.' In the ambassador's words, 'Our policy and his are diametrically opposed.' And the path forward was becoming treacherous: 'The tougher nut we are to crack, the less likely are we to be attacked but we must not underestimate the American danger and the tremendous military power of this country. As Oscar Wilde remarked it is easy to choose one's friends but one must be very careful in choosing one's enemies.' 1

Clearly, all was not quiet on the Republic's Western front. Taswell's anxiety was palpable, and tied to a simple, unavoidable fact-the first phase of the global struggle against apartheid was coming rapidly to its climax. Inspired by the political openings of second-wave decolonisation, African nationalists had rallied against South Africa in the wake of the Sharpeville Massacre in 1960, creating a coherent political bloc at the United Nations that was dedicated to eliminating white racism on the African continent. These efforts deepened and accelerated trends that began with first-wave decolonization in the late 1940s. By 1965, Third World nationalists had not only driven a wedge between south 
Africa and its traditional Western allies; they had transformed the dynamics of the Cold War. As one journalist observed that year, the apartheid question had become 'symbolic of bigger issues,' namely whether 'the demands of Bandung' would influence the nature of global power in the postcolonial era.2 Taswell's apprehensive telegram reflected the fears and suspicions of many white South Africans as they surveyed these developments in the mid-1960s. The citadel of white redoubt-constructed so methodically by South African leaders in the years after World War II-was now in the midst of a full-scale diplomatic siege. And former allies like the United states could no longer be counted on for moral, economic, or political support.

Historians have approached this complex moment from several vantage points. The majority of scholarship on South Africa was written between the 1970 s and the early 1990s, at the height of anti-apartheid activism in the United States and Great Britain. Inspired often by debates on disinvestment, this literature was primarily activist in its orientation and focused primarily on the economic connections between corporations in the United States, Great Britain, and South Africa. Many authors borrowed arguments from contemporary protest movements, and blamed 
the West for insulating the apartheid regime through its tacit acceptance of investment in South Africa.3 When applied to the world facing Taswell in 1965, the limitations of this literature are fairly self-evident. Most of these authors are uninterested in developments within the National Party and dismissive of tensions between South Africa and its Western allies. Adhering almost exclusively to the assumptions of the neo-colonial critique, these scholars paint pan-European power in monolithic, racist terms and flatten the complexities and contradictions of those who rejected white rule in south Africa.

Since the fall of the National Party, scholarship on apartheid in the $1960 \mathrm{~s}$ has grown more diverse. Among U.S. historians, the most notable contributions look at the links between the domestic civil rights movement and U.S. government policy toward South Africa. Recent monographs by Thomas Borstelmann, Robert Massie, and Mary Dudziak, among many others, illustrate how decolonisation transformed the boundaries of America's own racial revolution. Influenced primarily by methodologies of social and political history, these contributions often frame U.S.-South African relations along an imaginary color line that ran from Jim Crow America through the southern 
part of the African continent.4 Looking through the lens of a much different archival record, historians from South Africa offer an alternative vision of the period. For many, the most important aspect of the apartheid years was local activism by indigenous Africans. Drawing frequently upon narrative themes of resistance, these scholars add depth and texture to the historical record, and provide the 'New' South Africa with a usable past to deal with the contemporary challenges of racial reconciliation. Rather than highlighting the role of civil rights groups abroad, they focus often on exile organisations like the African National Congress, as well as subaltern peasants and workers in South Africa.5

My article aims to do something different. It blends multi-archival research with cultural analysis, treating the decade after second wave or African decolonisation as a global conjuncture when multiple actors competed to shape the terms of legitimacy at the international level.6 Using the apartheid question as a window on this process, I look specifically at how several influential global actors-the so-called African bloc, the National Party, and the U.S. government-tried to police knowledge about South Africa in these years. During this moment, South Africa's system of institutionalised racial domination came to function as a 
geopolitical site of contestation, rallying international opinions in concrete ways and infusing particular meanings into words like security, justice, development, and freedom.7 By highlighting the possibilities and limitations of change in the years after decolonisation, the debate over apartheid offers a unique microcosm of the postcolonial moment in the 1960 s.

This article looks at an important turning point in this story. Although downplayed or forgotten by many historians, the International Court of Justice (ICJ) case against South Africa was a transformative event. My analysis examines not only the evolution of the case between 1960 and 1966, but also the role it played in the larger political chess match between the National Party and the African bloc during this period.8 South African officials genuinely feared that a negative ruling would lead to sanctions or some type of armed conflict before 1967; African leaders fully expected that a positive ruling would reorient the terms of global legitimacy in their favor and validate the demands of the global south. The actual verdict delivered by the Court in late July 1966 surprised both sides and sent shockwaves through the international system, redefining the movement against white power in southern Africa. Viewed by many as the most 
important decision in the Court's history, the trial offers a unique window on how actors in the First and Third Worlds conceptualised-and contested-the notion of political order in the decade after decolonisation.

In exploring this story, this article is bound by two interlocking arguments. First, the ICJ case against South Africa was political. The primary aim of the African bloc in the early 1960s was to implement sanctions against the National Party and lay the foundation for an armed intervention of South West Africa. By the mid-1960s it was abundantly obvious that the Security Council-specifically the United States and Great Britain-would not accept General Assembly resolutions as evidence that South Africa's Mandate over South West Africa was a breach of international peace and security. If the African bloc could secure a positive ruling at the International Court, it would break the deadlock over these issues and force the great powers into action. In contradistinction, South African officials hoped a victory at the Court would fragment the international anti-apartheid struggle and eliminate the possibility of sanctions by the United Nations. In both scenarios, the case formed the pivot of a uniquely political game. 
At the same time, the ICJ case was about legitimacy. Both sides were drawn to the court because it represented a source of unbiased authority in the international system. Positioned as the linchpin of America's multilateral postwar political order, the court systemized and reified values for the global community.9 For the African bloc, the goal was not only to defeat South Africa, but to do so on uniquely postcolonial terms. By formally delegitimising the apartheid system, Africans felt they would translate the implications of universal human rights into international law and verify the moral power of the nonwhite liberation struggle. The stakes were equally high for the National Party. A victory would not simply insulate the government from sanctions and armed intervention; it would effectively buttress South Africa's assertion that sovereignty trumped universal equality in the postcolonial era. If anti-apartheid activism could be framed as a mere side show in the larger drama between liberal capitalism and communism, South Africa would be free to reposition itself as the West's principal ally on the African continent.

When viewed within these frameworks, the ICJ case emerges as a watershed moment. The Court's verdict was delivered during a period of remarkable turmoil in the 
international system. Third World nationalists who had rallied to the United Nations in the years after decolonisation were beginning to lose their faith in the organisation by the mid-1960s. The outcome of the ICJ case reflected and reinforced these trends. It became a powerful symbol, dramatising the limitations of change in the postcolonial era and foreshadowing future directions in the struggle against apartheid in southern Africa.

\section{APARTHEID'S ACHILLES HEEL}

Kenneth Kaunda was an emerging African leader in 1964. As the Prime Minister of the most recently liberated nation in Africa, he was invited to the semi-annual Conference of Non-Aligned Countries in Cairo, Egypt, that autumn to speak on behalf of the Zambian people. His speech to the conference centered on one basic theme-now was not the time for new looks on Third World issues.10 His speech opened with a few words on the continued moral clarity of nonalignment, then shifted into an extended diatribe on white power in southern Africa. Noting that the 'forces of reaction' still loomed large over Africa, Kaunda pointed specifically to the Republic of South Africa, arguing that apartheid would 'reap the whirlwind of disaster' if it continued to violate 'reason and the fundamental principles 
of civilisation and humans rights.' His solution was deceptively straight-forward-a renewed commitment to the 'diplomacy of peace.' White redoubt could only be defeated through international action. 'We all know that the United Nations Organization is the only key to international and national security,' he explained. '[I]t is through the strength of the General Assembly that the non-aligned nations will be secure until all the powerful nations are politically, economically and socially just.' 11

The speech was an important moment in Kaunda's embryonic political career. Wrapped in the language and logic of Third World nationalism, it helped position him to succeed Gamal Abdel Nasser as the Secretary General of the Non-Aligned Movement. It also revealed many of the assumptions that animated nationalist thought among Third World elites in the mid-1960s. For leaders like Kaunda, apartheid was an affront to the very concept of nonwhite political liberation. Since the onset of first-wave decolonization in the 1940s, South Africa's racial policies had served as an imaginative foil for much of the decolonized world, providing an array of politicians with a common enemy at the international level.12 Kaunda's comments showcased how many of these actors conceptualised action against the monolith of white redoubt. The best 
strategy was not guerilla warfare or aid from communist powers but diplomacy at the United Nations. For Kaunda, the numerical superiority of African and Asian countries at the General Assembly was significant. Non-aligned nations did not just have a seat at the table; they had the right to control the conversation on North-South issues. They had the right to use the U.N. to confront white racism in Africa.

Kaunda's speech offers an ideal vantage point on the international anti-apartheid movement in the years surrounding decolonisation. This was a struggle defined not by Western liberals, church leaders, or even civil rights groups in the United States, but by nationalists from the Third World. As Frederick Cooper and others illustrate, these nationalists adhered to a metanarrative that blended modernisation with non-racialism and equated national liberation with socio-economic progress.13 By the mid-1960s, their fight against apartheid had reached a paradoxical crossroads. On the one hand, postcolonial nationalists had successfully forced the United Nations Security Council to pass an arms embargo against the Nationalist government and connected the question of apartheid to the broader constellation of colonial issues in Southern Rhodesia, Angola, and Mozambique. However, the 
major prizes-economic sanctions and military interventionwere still out of reach. Although the African bloc and its allies could pass General Assembly resolutions against South Africa with ease and frequency, they found it nearly impossible to move the Security Council beyond a position of symbolic criticism vis-à-vis apartheid.

Members of the African bloc understood these difficulties well. In the early 1960s many had hoped the General Assembly would push the Security Council past this tipping point through article 14 of the United Nations Charter, which gave the Assembly the ability to 'recommend measures for the peaceful adjustment of any situation . . it deems likely to impair the general welfare or friendly relations between nations.' African nationalists had initially believed that if they demonstrated that South Africa was a danger to 'the maintenance of international peace and security,' the Security Council would be obliged to take action under the provisions of chapter VII, which outlined the Council's role in dealing with member-state aggression.14 By 1964 it was clear that this would not happen. The United States and Great Britain-with their sizeable economic investments in the Republic and positions of influence on the Security Council-were simply unwilling to accept U.N. General Assembly resolutions or Special 
Committee reports as proof that South Africa was a direct threat to international peace.

Faced with this impasse, African nationalists shifted their strategy. If progress in the political realm had reached its natural boundaries, the alternative was action through the system of international law. Stated plainly, the answer was the International Court of Justice. This approach was not entirely unfounded. U.S. planners, inspired by the achievements of the New Deal, had used the ideology of liberalism to rationalise America's 'preponderance of power' in the late 1940s. The international system they created was based not on power politics and intimidation, but legal structure and multilateralism.15 This framework opened a range of pathways for Third World activists in the decade after decolonisation and, so long as the great powers were committed to this liberal international order, a victory against South Africa at the International Court would have serious repercussions. Article 94 of the U.N. Charter explicitly bound the Security Council to uphold Court judgments. In the minds of many African strategists, a legal victory against apartheid at the court would put the United States and Great Britain in a political checkmate, 
forcing both countries to choose between concrete action against South Africa and a veto in support of Pretoria.

The Republic's controversial Mandate over South West Africa offered an ideal basis for litigation. The League of Nations had entrusted South Africa with a Class ' $C$ ' Mandate over Germany's colony following World War I. In theory, this Mandate was to become a United Nations Trust Territory after World War II, but South African leaders made an aggressive power play in the late 1940s, arguing that because the United Nations was not the natural successor to the League of Nations the territory no longer belonged to the international community. In their minds, there was no transfer of power between the League and the U.N. As such, South West Africa was now sovereign to South Africa. The United Nations responded to this challenge methodically, soliciting the views of the International Court of Justice in a series of advisory opinions in the early 1950s that denounced Pretoria's actions as insolent and unlawful. However, the Court's advisory rulings were nonbinding and South Africa's intransigence went largely uncontested through the 1950s.16 All the African bloc had to do was prove in a contentious hearing that South Africa's Mandate was illegitimate. The legal basis for 
action against apartheid would immediately be established at the United Nations.

A victory on this front would be a major accomplishment. With the Rivonia Trials of early 1964 the National Party had effectively put to rest the notion that it would succumb naturally to internal pressures from the African National Congress (ANC) and Pan-Africanist Congress (PAC). South Africa, in the words of one journalist, was not going to be the 'next Algeria.' 17 Most observers abroad were dejected by this turn of events. 'South Africa's monolithic police state with all its ramifications of spies and informers makes it impossible for organized violence or boycotts to be planned,' lamented one activist at an international conference on apartheid in 1965.18 The South West Africa Mandate, however, was the chink in the seemingly impenetrable armor of white power. In the mind of many African leaders, the region represented 'the Achilles heel of apartheid.' While the National Party could use notions of sovereignty to shield its internal policies from international criticism, its position in the Mandate territory was tenuous at best. In the words of one African nationalist, South West Africa was not only a 'major issue in world politics,' but also a 'flashpoint in the international struggle against apartheid-involving not 
only African nations but the great powers as well.'19 Victory would be more than symbolic. It would create the legal rationale for a roll-back process that stopped only at Table Mountain in Cape Town.

The African bloc announced it would bring litigation against the Republic in late 1960. Although most African countries provided resources to pay for trial expenses, Ethiopia and Liberia coordinated the effort because they had been members of the League of Nations when the Mandate was originally conferred on South Africa. The first hurdle of the case was a large one. The African bloc needed to confirm that it had a legal basis to challenge the Republic's policies in South West Africa. To develop their strategy, the Applicants hired a New York-based lawyer with extensive experience in the U.S. State Department-Ernest A. Gross. Gross had written extensively on the role of the United Nations in promoting international peace and justice, and African leaders viewed him as an ideal ally. According to Enuga Reddy, a U.N. official who worked closely with African leaders in the 1960s, Gross was 'chosen as the counsel in the hope that he would influence the U.S. Government.' 20 The African Group's aim was not just to win the case but to push the United States and 
Great Britain into the worldwide coalition against apartheid.

Gross approached the job from an equally distinct vantage point. The fifty-four year old liberal lawyer viewed the trial as a chance to rectify the growing tension between the politics of postcolonialism at the General Assembly and the politics of the cold War at the Security Council. In the vernacular of modern legal theory, he was an advocate of 'transitional justice.' As historian Elizabeth Borgwardt explains, this paradigm embraced 'an alternative way of thinking about the relation of law to political transformation,' treating justice as 'distinctive in times of transition-partial, contingent, and shaped by social understandings of prior injustice rather than by abstract, idealized conceptions of the rule of law.'21 In Gross's mind, decolonisation represented the major transformation of the late twentieth century. 'New nations explode into being, not like stars in space, but as neighbors on a crowded planet,' he wrote in 1962. 'New opportunities bring need for corresponding changes in process and structure.' If the history of man was a story of 'endless struggle toward durable peace and a just order,' South Africa was important for one reason-new nations emerging on to the world stage viewed apartheid as 
an impediment to further human progress. As such, it needed to be confronted.22

Gross explained his mindset on South Africa well during an informal lunch with American officials before he accepted the African bloc's job offer in 1960. According to notes of the meeting:

Gross said the importance of SWA has often been overlooked because of the broader problem of apartheid in the Union. In his view the problem of South West arose because of apartheid and was inextricably tied up with it. . . [ [By] using South West Africa to bring additional pressure against the Union, [the Mandate] might be a handle to get at the apartheid question itself. He said this gave added emphasis to the question of timing and tactics since at some point the question of South West Africa and apartheid would . . merge into one effort.23

This mindset shaped Gross's strategic approach during the initial phase of the case in 1961 and 1962. As counsel to the African bloc, he articulated a two-pronged legal assault that cast the situation in wide terms. The first step was proving that the South West Africa Mandate still existed. Drawing heavily upon the Court's own advisory 
opinions, Gross's initial Memorial asserted that the General Assembly had replaced the League Council as the primary oversight organisation of the Mandate System.24 Despite South Africa's assertions to the contrary, the Republic had tacitly accepted the authority of the United Nations in 1946 by requesting feedback on whether South West Africa could be annexed by Pretoria. It was only after this request was denied that Nationalist leaders fell back to the thesis of discontinuity. According to Gross, these points meant the Mandate was still an 'autonomous territory' with 'international character.'25 As such, the South African government was obliged to provide regular reports and petitions to the United Nations and submit to the general will of the world community.26 This argument was the linchpin of Gross's case. If the court rejected the claim that South West Africa was within the basic jurisdiction of the United Nations, the Applicant's case would collapse before it even began.

The second part of the African bloc's legal assault focused on the terms of the Mandate. Gross went through the original document with methodical care, emphasising how the South African government had debased its territorial responsibilities and violated the human rights of indigenous peoples. Despite the fact that article 4 of the 
Mandate explicitly prohibited the creation of army or navy bases in the territory, the Republic had done exactly the opposite. 'Armoured corps are not normally used for police protection or internal security,' Gross noted with a hint of sarcasm in 1961.27 South Africa was deliberately turning the territory into a buffer zone for white power, stifling local independence movements while ignoring the development needs of the people.28

Human rights questions were featured prominently in the Memorial. Hearkening back to article 2 of the Mandatewhich instructed South Africa to 'promote to the utmost the material and moral well-being and social progress of the inhabitants of the territory'-Gross's legal team provided nearly one-hundred pages of self-proclaimed factual evidence on the 'well-being, social progress, and development of people in the territory.' 29 Their analysis constituted a veritable tour d'horizon of Western development theory in the early 1960s, and focused on how South Africa had retarded the economic growth, representative government, citizenship rights, freedom of movement, personal security, rights of residence, and educational opportunities of people living in South West Africa. The result was a damning portrait of neglect.30 
The logic undergirding Gross's legal brief was fairly self-evident. If the Mandate System was built on a 'sacred trust' between the Mandatory and indigenous people, south Africa's policies of apartheid breached this agreement. As such, the Mandate needed to be revoked. The New York lawyer was modeling Africa's case on the most prominent human rights trial of the twentieth century-the Nuremberg Trials. Like the litigation against Nazi Party leaders in the 1940s, his argument centered on the idea that inhumane acts committed against civilian populations were indictable as 'crimes against humanity.' Gross also understood thatlike the Nuremberg Trials-the South West Africa case would function as a contest over the meaning of human rights and justice in the decolonized world. It was essential, therefore, that his attacks link the Republic's failures in the realm of development with its support of inequality and racial separation.31 Progress was simply incompatible with apartheid in the postcolonial era. In his words:

[T] he Mandatory has not only failed to promote 'to the utmost' the material and moral wellbeing, the social progress and the development of the people of South West Africa, but it has failed to promote such well-being and social progress in any significant degree whatever. To 
the contrary, the Mandatory has thwarted the well-being, the social progress and the development of the people of South West Africa throughout varied aspects of their lives. . . . The grim past and present reality in the condition of the 'Natives' is unrelieved by promise of future amelioration. The Mandatory offers no horizon of hope to the 'Native' population. 32

This vision of social justice was tied closely to the symbolic matrix of Third World nationalism. Non-indigenous governance ispo facto was an inhuman act. Therefore, it followed that political independence-defined literally as control of fixed territorial space-formed the gateway to economic and social development. A victory on these terms would not only provide the legal basis for concrete action against the Republic of South Africa. It would institutionalise the connection between apartheid and moral iniquity and establish a fulcrum to reframe global norms around postcolonial objectives.

These stakes were not lost on the Nationalist government. Afrikaner elites combated the global antiapartheid movement through a multi-faceted program of propaganda, political resistance, and grassroots lobbying 
during the early 1960s. Their goal was not to engage African nationalists directly in a debate on human rights, but to work outside the parameters of the United Nations to subtly reframe the nature of the conversation on apartheid.33 The National Party's initial response to the Applicant charges at the International Court fit into this initiative. The government put its faith in David P. de Villiers, a prominent member of the South African Bar with close ties to Prime Minister Hendrik Verwoerd. Not surprisingly, his philosophical attitudes on international law contrasted starkly with Gross's 'transitional justice.' An ardent political and social conservative, de Villiers supported a static vision of global order based on national sovereignty and historical tradition.

In forming South Africa's response to the Memorial, de Villiers's legal team tried to do an end-run on human rights questions by focusing exclusively on the status of the South West Africa Mandate. Their argument unfolded in four parts. Wrapped around a sophisticated interpretation of Western contractual law, the first point claimed that the Mandate could not be viewed as a binding legal agreement because the resolution that created it was termed a 'declaration' rather than 'treaty or convention.' 34 When South Africa refused to recognise the jurisdiction of the 
United Nations in 1945, it followed that the Mandate ceased to exist.35 The second and third points attacked the locus standi of Ethiopia and Liberia. Pushing the boundaries of circular logic, South Africa asserted that because no country still belonged to the League of Nations, it was technically impossible to challenge South Africa's control over South West Africa. Drawing again on the specific language of the Charter, South African lawyers rationalized this claim by pointing out that article 7-which outlined proper recourse in the case of a dispute over South West Africa-did not say that 'former' League members could challenge the Mandate. The third point made this argument in a slightly different way, speculating that the Applicants could not technically have a dispute with south Africa anyway because Mandatory powers were answerable only to the League as an entity. Individual states had no standing.36 Finally, de Villiers's team sought to delay the litigation, claiming that 'direct diplomatic intercourse' between the Applicants and South Africa had yet to take place. Previous discussions at the United Nations were meaningless because they had been conducted in a 'charged political environment.' Until the Republic was given 'a real and genuine opportunity to negotiate it can not be 
said that the dispute is one which cannot be settled by negotiation.' 37

South Africa's efforts were almost successful. In a narrow eight-to-seven decision just before Christmas 1962, the Court accepted the first part of Gross's argument. The Mandate existed despite the dissolution of the League, and Ethiopia and Liberia had the right to challenge South Africa's policies in South West Africa. As one legal scholar explained at the time, the decision symbolically indicated that the 'sacred trust' would not be 'allowed to go by default and just disappear into thin air.'38 The Nationalist government was accountable for its actions in South West Africa. In an opinion that foreshadowed the next stage of the legal battle, one prominent judge explained that the law was a 'living phenomenon which translates the collective exigencies and necessities of each historical moment.' Noting that the 'social occurrences' of each era were the most important sources of global order, he explained, 'Law is not just a mental abstraction, nor the result of repeated application of written jurisprudence, but, rather, a norm of conduct which is rooted in social intercourse.' 39 The implications were obvious-momentum was on the side of Gross's 'transitional justice.' 
FROM NUREMBURG TO BROWN

For the Nationalist government, the Court's decision constituted just one part of the much larger-and universally unfavorable-political landscape of the early 1960s. As one South African journalist lamented, the Republic's 'spiritual place in the world [was] disappearing.'40 Indeed, attacks on South Africa were coming from several directions. On the one hand, the country's position in the Western bloc was under fire. The Republic was effectively removed from the British Commonwealth in 1961 when it refused to implement nonracial domestic reforms demanded by Ghana, Nigeria, and India, and it was subjected to an arms embargo by the U.N. Security Council in mid-1963 when the Kennedy administration bowed to the pressure of the so-called AfroAsian bloc. At the same time, South Africa's position in southern Africa was unstable. As historian Susan Onslow demonstrates, the Republic's relationship with Rhodesia was wrought with tension as Ian Smith prepared the country for its Unilateral Declaration of Independence.41

By the mid-1960s, South Africa stood at a difficult crossroads. In the words of Prime Minister Verwoerd, the 'crux of the problem' was whether being in the 'good books 
of world opinion' mattered as much as 'ensur[ing] the survival of the white race in this country.'42 The answer was obvious to most high-ranking government officials-even if the consequences were not. Despite a constant stream of propaganda on South Africa's economic and political invulnerability, many officials understood that the country's long-term prospects were entwined intimately with the world situation. According to Foreign Minister Eric H. Louw, South Africa could weather criticism from the United Nations General Assembly, but the 'attitude of those countries outside the Bandung-Communist combination,' namely the United States and Great Britain, posed a 'serious threat' to South Africa's continued prosperity.43 And as one top-secret review admitted, the 'good-will, aid and investment' of the West was simply 'more important to South Africa than vice versa.' 44 With the United States embroiled in its own civil rights revolution and the apartheid debate sitting at the nexus of postcolonial politics at the United Nations, this uneven relationship meant trouble for the Republic.45

It was in this environment that the second phase of the ICJ case took on tremendous significance. Viewed widely as an unbiased institution of law, the court provided a forum where values were contested and normalized 
for the international community. If the logic undergirding Gross's second argument was accepted by the Court, it was entirely possible that attitudes toward South Africa's situation would harden into outright hostility. As de Villiers explained to his superiors after South Africa's legal defeat in 1962, the ICJ case was one of the 'greatest threats facing the Republic.'46 A victory, on the other hand, would carry substantial dividends. If the Nationalist government could show that apartheid in south West Africa was not a violation of human rights-if it could decouple concepts of justice from the nonwhite liberation narrative-the government would gain a leverage point to reverse trends toward confrontation with the West. In the minds of South African officials, the ICJ case was the tipping point in the larger contest over the Republic's future in the Western bloc.

South Africa's legal strategy during the second phase of the trial was elaborate. Not surprisingly, de Villiers opened his case by rearguing his original claims on the nature of the Mandate and U.N. succession. He sharpened the thesis of discontinuity by positing that the Mandate was accountable not to a nebulous 'international community' but to a concrete institution-in this case the League of Nations. Consequently, it was not possible for a wholly 
different institution to have supervisory powers without the Republic's consent. The African bloc's evidence that South Africa had given this consent tacitly in 1946 was countered with a series of previously undisclosed 'new facts' that delved deep into the minutiae of the historical record, drawing on a constellation of minor points to muddy the clarity of Gross's original argument.47 Recognising that the Court had already ruled on this issue in 1962, de Villiers tried reframing the Court's decision as a narrow verdict on jurisdiction rather than an expansive judgment on the discontinuity thesis. This assertion was not entirely true, but with the Court divided eight-to-seven a South African breakthrough was not impossible. If one judge accepted the validity of the Republic's 'new facts,' the original basis of the case would have to be reconsidered. And without evidence of consent, Gross could be pushed into a corner where he would have to argue that the 'international community' had boundless supervisory powers over nation-states in the world-system.

The meat of South Africa's case was its rebuttal of the African bloc's characterization of apartheid in South West Africa. For de Villiers, everything pivoted on showing that segregation could not be conflated with oppression. In a brief that totaled over 1,400 pages, his 
legal team challenged both the factual and conceptual accuracy of Gross's initial Memorial, explaining that apartheid did not retard social progress but offered each racial group the tools for 'separate development.' Far from functioning as an agent of race hatred, this program allowed South West Africa's 'major ethnic groups to achieve an increasing measure of self-government and to develop toward self-determination in a political and territorial entity of its own.'48 The Republic's rationalisation of its approach was twofold. In defensive terms, South African lawyers claimed it was unfair for the white community to sacrifice its 'institutions, its culture [and] its heritage' in the face of a 'numerically preponderant and aggressively nationalistic Bantu population.'49 Drawing on popular binaries between civility and barbarism, they suggested that South Africa's demographic and historic particularities made multi-racialism a dangerous myth. At the same time, de Villiers and his associates cast separate development as a positive alternative to the 'cultural imperialism' of 'European universalism.' Rejecting the language of early twentieth-century racial thought, South Africa used social science to show that ethnic groups were 'different' in objective ways and deserved the chance to develop in line with their own 
standards. Quoting Prime Minister Verwoerd, de Villiers asserted that this program was not a byproduct of white supremacy, but a practical way to allow groups to live 'next to one another as good neighbors and not as people who are continually quarrelling over [power].'50 The issue was not racism but conservative Christianity. Apartheid, in this depiction, was South Africa's practical response to the Biblical lessons of Babel.51

On the strength of this framework, de Villiers proceeded to reject each accusation of the Applicant's Memorial. In the economic realm, he asserted that whites were more powerful than indigenous people in South West Africa because Natives were uninterested in private property and modern capitalism. Drawing on ethnographical evidence and expert testimonies, South African lawyers suggested that most Africans chose to remain independent of the 'money economy' because they preferred subsistence farming and local trade networks. Those individuals who bucked these trends generally gravitated to regional mining industries, where they avoided trade unions because of their illiteracy and linguistic diversity. Framing government policy in munificent terms, de Villiers suggested that Nationalist officials only represented 
Natives on labor boards so that their welfare was protected from 'unscrupulous troublemakers.' 52

The same principles applied to the political realm. Although Africans were not allowed to participate in white political institutions, they were given complete control over their local, tribal, and territorial affairs. The Applicant's suggestion that these Native Reserves-or Bantustans-were unfunded and overcrowded was placed next to South Africa's widely publicized Odendaal Report, which promised to spend over $£ 75$ million on a five-year social modernisation program in the territory. It would probably take 'one-hundred years or more' to get indigenous people ready for full self-determination, but the Nationalist government was willing to commit the necessary resources.53 Finally, in the area of education, South African lawyers framed apartheid as an agent of development. In their minds, direct comparisons between white and nonwhite education levels were deceptive because African 'tribes' were so widely opposed to universal European instruction standards. Education was a source of identity and power for local groups. Nationalist officials coupled this point with evidence that, despite these barriers, the government was able to increase school attendance among African children by forty-six percent between 1950 and 1961; a 
number which compared favorably to Ethiopia's five percent and Liberia's twenty-three percent.54 Returning to article 2 of the Mandate-which instructed the Mandatory to 'promote to the utmost the material and moral well-being and social progress of the inhabitants of the territory'-South Africa concluded that Gross's entire case was baseless. Despite hollow assertions to the contrary, apartheid was implemented in good faith in South West Africa, proving that racial separation was not incompatible with the project of development.55

To hammer this point home, South Africa made a bold move as oral arguments commenced on 30 March 1965. Standing before the court for the first time since 1962, de Villiers invited the judges to conduct an on-site inspection of South West Africa. The only condition was that they also visit Ethiopia, Liberia, and a former Mandate territory like Tanzania. With this comparative understanding of the 'African reality,' the Court would be better equipped to 'form a general impression of comparable conditions and standards of the material and moral wellbeing and social progress of the inhabitants.'56 The request was a shrewd tactical maneuver-designed to link African problems with racial inferiority rather than colonial injustice. De Villiers understood that Gross was 
modeling his case on the Nuremberg Trials, and hoped the invitation would highlight the flaw which undergirded the historical analogy. The Allied case against Nazi Germany's leadership-class worked because American lawyers could show that German policies resulted in the wholesale violation of human rights during World War II. If the Nationalist government could prove through concrete, comparative evidence that its policies were not resulting in the ends alleged by the Applicants, South Africa's critics-or at least the members of the International Court-would be forced to reassess the basic charge against apartheid. The National Party's racial policies certainly stood in juxtaposition to trends toward self-determination in the Third World. But that did not necessarily mean apartheid was 'genocide masquerading under the guise of a civilized dispensation of justice.' 57

The gamble paid off. Gross's legal team was surprised by the South African move. Stridently refusing to accept the proposal, the Applicants claimed that such a trip would sap the Court's resources and unnecessarily extend the trial. It was 'unnecessary, expensive, dilatory, cumbersome and unwarranted.'58 However, as some observers pointed out at the time, 59 Gross's declarations masked the fact that de Villiers had placed the African bloc's lawyers 
in a genuine catch-22. Without tangible evidence of oppression in South West Africa, the case against apartheid lacked substance and depth. But to obtain concrete evidence of oppression, members of the African bloc would have to open their own internal policies to scrutiny and examination. In essence, de Villiers was asking his opponents to move their charges from the realm of rhetoric into the world of reality. If the court went through with the trip and supported South Africa's argument, the rationale of the Third World's international political program-in particular the argument that political liberation formed the gateway to economic development-would be discredited. In de Villiers' own words, the dilemma was 'unenviable.' 60

Gross responded by moving the case to purely theoretical grounds. Although he intended to systematically challenge each point of South Africa's Counter-Memorial, he announced in early April that the Republic's entire brief had been 'immaterial.'61 The issue was no longer oppression in South West Africa, but the fact that the South African government's policies violated the 'international human rights norm of non-discrimination or non-separation.'62 According to Gross, this norm was created by the United Nations Charter and the Universal 
Declaration of Human Rights and solidified in the early 1960s with the General Assembly's Declaration on the Elimination of All Forms of Racial Discrimination.63 Although it did not explicitly trump South Africa's national sovereignty, it gave 'specific and objective' meaning to international agreements like the Mandate and bound international organizations such as the United Nations to certain forms of behavior.64 The implications were self-evident when applied to the South West Africa case. Article 2 could not be upheld without a parallel commitment to non-discrimination and non-separation. As one legal expert explained at the time, 'The sole issue [now] was the existence of an international legal norm which absolutely and categorically prohibited apartheid. Neither South Africa's motives in instituting apartheid in South West Africa, nor the effects of that policy on the territory's inhabitants were now at issue.'65 In Gross's mind, the ball was back in South Africa's court. However, this line of reasoning dramatically changed the rules of the game. Gross was now modeling the African bloc's case not on the Nuremberg Trials, but on America's own Brown v. Board of Education. Because 'separation [was] inherently unequal' it followed that apartheid automatically suppressed human rights in South West Africa, 
irrespective of the evidence presented by the Nationalist government.66 Linking this situation directly to U.S. domestic law, Gross argued, 'The Respondent's policy of racial segregation in. . the Territory is even more affirmative, explicit and far-reaching than the racial bar struck down by the Brown decision.'67 And if the United States government-the most powerful political entity of the postwar era-was willing to support the norm of nondiscrimination, it followed that the court would have to deliver a judgment against racial separation in South West Africa.

Gross was getting to the same end-the incongruity of apartheid and development-through different means. During the initial phase of the trial, the African bloc's case pivoted on the idea that apartheid was illegitimate because it impeded the development of local South West Africans in tangible and observable ways. This argument did not fundamentally change during the second phase of the trial, but the emphasis shifted from local dynamics to international structure. In very natural ways, the raison d'être of the African position came to the forefront. The case was as much about legitimizing postcolonial discourse as it was about the intrinsic morality of events in south West Africa; apartheid was significant not only because it 
oppressed black South Africans but because it held symbolic importance at the international level. Through its theoretical sophistication and political intransigence, apartheid challenged the very idea that history was moving linearly toward a political order based on nonwhite liberation, human rights, and economic development. And faith in this narrative, in many ways, was the source of the Third World's power in the first decade after decolonisation. By reframing the charge against the Nationalist Party around the global norm of nondiscrimination, the Applicants sought not only to invalidate the logic and rationale of South Africa's policies, but also to reify the authority and prestige of the Third World's political agenda.

This shift was a huge leap for the Court. Beyond the basic quandary of whether one sovereign's domestic law had universal, transnational value was an even greater question: Was there a single moral system for the world? Gross felt that if he could convince the court that such a system existed, he would obtain a favorable ruling on apartheid in South West Africa. Even more, a positive judgment on these terms would institutionalise a new balance between traditional 'European' notions of global order-based on the restrictive concept of national 
sovereignty-and an emerging 'postcolonial' vision of power based on universal human rights. The implications of the argument were extraordinary. But, as de Villiers had envisioned, the Applicant case now rested on tenuous, uncharted ground. Did the 'international community' truly have boundless supervisory powers over nation-states in the world-system?

\section{HISTORICAL INEVITABILITIES}

This contest did not unfold in a vacuum. Put plainly, litigation at International court mattered because Washington was listening. Having created the basic scaffolding of the postwar international system, the United States gave life to notions of transnational law and enforced the Court's authority at the United Nations Security Council. U.S. leaders may not have been emotionally vested in the issues discussed at The Hague, but American attitudes nonetheless shaped the lines around what was politically possible in the outside world.68

U.S. policy toward apartheid was conflicted in the 1960s. On the one hand, the state Department tended to treat the National Party as a political and propaganda liability. With the creation of the African Bureau in the late 1950s, liberals such as G. Mennen Williams and Arthur 
Goldberg obtained an institutional platform to push the United States toward confrontation with the Republic. Like Third World nationalists and South African officials, they often couched their goals in the language of development, subtly equating Africa's aspirations with America's own commitment to 'democratic principles, interracial society and human welfare.' These individuals did not see the same linkages as African leaders like Kaunda, but they generally accepted a progressive vision of history and social justice.69 Apartheid was significant, in this regard, because it distracted Third World leaders from the benefits of Great Society liberalism and pushed the region into an unnecessarily combative anti-Western stance.70 Robert Komer, the President's Deputy Special Assistant for National Security Affairs, framed these fears well in November 1965, saying that if America failed to back the anti-apartheid movement it would be viewed as opposing the 'historically inevitable' rise of African majority rule.71 Few members of the State Department equated support for African nationalism with an armed intervention against South Africa, but many felt sanctions against the National Party would eventually become unavoidable.72

In contradistinction, the Pentagon, Joint Chiefs of Staff, and Central Intelligence Agency tended to frame the 
Nationalist government as America's main ally in Africa. Placing precedence on concrete U.S. interests in the region-namely a NASA tracking station and over $\$ 600$ million worth of private investment-they consistently castigated the 'radicalism' percolating through the state Department. Maxwell Taylor, the Chairman of the Joint Chiefs of Staff, put it best, 'As long as communist penetration and racial discord in Africa remain an active threat to Free World interests, stability in South Africa is desirable and the United States should do everything that its political and moral position permits to contribute to this.'73 Self-rule in the Third World might have been historically inevitable, but that did not negate U.S. national security interests or lessen the dangers of the Cold War.

In the mid-1960s, President Johnson generally sided with the State Department. 'I feel that the prime determinant of U.S. influence in Africa will be the stance the U.S. takes on those political issues of primary concern to the Africans themselves,' he explained in a private memo to Secretary of State Dean Rusk in November 1965. 'U.S. concern for African problems must be demonstrated by actions, and in terms, which will have an immediate appeal to the people of Africa.'74 The result was a foreign policy that tilted toward confrontation with South Africa. 
Although a workable solution was admittedly 'difficult to identify,' the U.S. national policy review on the Republicdeemed 'comprehensive' and 'authoritative' by the Johnson administration-nonetheless opened with the declaration that the 'status quo' needed to be overturned in the region. The authors presented a conceptual map that mirrored the African bloc's own understanding of the situation. While the rest of the world was 'moving fast in one direction,' the South African government was 'moving fast in the opposite direction.' And with the United States' own racial situation 'in an acute stage of resolution,' a tepid approach toward apartheid was no longer acceptable.75 However, opposition to South Africa did not automatically mean support for the African bloc at the United Nations. As historian Tim Borstelmann and others highlight, Johnson viewed himself first and foremost as a 'moderate man of the political center.'76 His decision to confront South Africa was driven not by genuine moral concerns with apartheid, but by an overriding desire to coopt the energies of black and white extremism at home and abroad. The question was one of control. Like any power structure, the liberal international order constructed by U.S. leaders in the late 1940s functioned because memberstates around the world tacitly invested in its authority. 
Apartheid challenged this balance in two interlocking ways. Most obviously, it distracted attention from America's own goals and obfuscated the moral primacy of liberal

internationalism. On a deeper level, however, South Africa's refusal to adjust its policies in the face of General Assembly criticism-and the Security Council's reluctance to punish the apartheid government for its obstinacy-eroded faith that the U.N. could be an agent of social justice. When taken together, these trends spelled trouble for the United States. In the minds of many liberals, the intellectual infrastructure of American hegemony was buckling under the weight of postcolonial politics. A new 'status quo' in South Africa would not only counteract these trends, but it would also help the United States reconsolidate its political authority in the decolonized world.

The case at the International court focused these abstract concerns in concrete ways. As the State Department explained, the trial was the first major confrontation between the world community and South Africa' and a major challenge to the 'authority of the U.N.' 77 The Johnson administration's overriding goal was to avoid the African bloc's 'all-or-nothing' checkmate and prevent an angry explosion at the U.N. General Assembly.78 Assuming 
that the ICJ judgment would go against South Africa on all counts, officials tried to preempt the consequences by mollifying the Nationalist government's policies in south West Africa. They adopted an aggressive tactical initiative. Not only was the arms embargo of 1963 continued, but the state Department began removing NASA and DOD facilities from South Africa and asked lending agencies to suspend economic activity with the Republic.79 On an informal level, Assistant Secretary of State G. Mennen Williams and the African Bureau further coordinated a series of meetings with prominent businessmen to discourage investment in the Republic.80 Even the Pentagon got involved, canceling the U.S.S. Independence's port call to Cape Town in May 1965.81 These efforts were coupled with a series of planning papers that explored the feasibility and desirability of economic sanctions and/or military action in southern Africa.82 By the end of the year, the United States-working in conjunction with Great Britain-was in the midst of a full-scale diplomatic battle with the Republic over the implementation of the Odendaal Report.83 This culminated with a pair of Aide-Mémoires in 1965 and 1966 suggesting, with calculated subtlety, that the West would support economic sanctions if South African officials failed to comply with the ICJ decision.84 
This turn of events surprised Pretoria. Writing from Washington in 1965, ambassador Taswell speculated that the U.S. public was being 'softened up' for an attack on the Republic. South Africa's 'most dangerous enemies' were those out 'to win the Negro vote in the United States and win the goodwill of the black man in Africa and the AfroAsian group as a whole.' For these individuals, the 'white man in Africa' was merely an 'expendable obstacle.' 85 Others pushed against such 'over-simplified' sentiments. 'The majority of the United States policy-making elements [are] not yet aware enough of the South African situation to have fixed views for or against,' lectured Donald Sole, the Deputy Secretary of Foreign Affairs. 'In simple terms, we are not 'Communists' nor are we 'Fascist' enough (vide Franco) to be classified as 'enemy.'' There was still time to improve U.S.-South Africa relations.86 M.I. Botha, South Africa's U.N. representative in the mid-1960s, agreed with this sentiment, but still felt the United States was guilty of ideological hubris. The Americans, in his mind, were incapable of distinguishing between the racial situation in the United States and that in South Africa. To them nationhood is somehow only nationhood in the image of the United States which is an all-embracing nation-as Whitman called it, 'a nation of nations.' '87 
This intellectual egotism did not bode well for the Republic. Nationalist officials were angered primarily by the United States' unwillingness to acknowledge that the trial itself was tipping definitively in South Africa's favor. De Villiers spent much of 1965 burying the Court under documentary evidence and highlighting the implications and contradictions of Gross's norm of 'nondiscrimination' and 'non-separation.' Turning the concept on the Republic's enemies, he argued first that the internal policies of India, Liberia, Ethiopia, and dozens of other states in Africa, Asia, Europe, and North America fully supported ethnic, economic, religious, and racial stratification. Although the ideal of 'non-discrimination' was rhetorically ubiquitous at the United Nations General Assembly, the concept still did not exist concretely anywhere in the world.88 Furthermore, if the court accepted the logic of the Applicant's accusation, it would open the door for infinite, unrestrained, and politically-charged litigation at the International Court. Would 'untouchables' in India be able to attack their government for its legacy of discrimination? Were African Americans entitled to prosecute the United States for housing and employment segregation? De Villiers did not provide answers to these questions, but his message was clear: 
Human rights were not static, self-evident, or onedimensional. They were fluid and subjective conceptual instruments used by actors with particular political agendas .

The second part of de Villier's counterattack tried to highlight the 'true' origins of Gross's legal strategy. Drawing selectively on expert knowledge from Europe, South Africa, and the United States, South Africa's lawyer presented a litany of witnesses to lament the 'indiscriminant use of racial discrimination, segregation, separation, apartheid, [and] Nazism' at the General Assembly, and bemoan apartheid's false association with racial superiority, doctrines of expansionism, and racial hatred. Politics rather than 'law and history' were driving these linkages.89 Once de Villiers established this point, he turned his attention again to South Africa's own policies. Adeptly wrapping his country's social program in the language of social science, he contrasted the African bloc's 'fairytale' history of global unity with the Republic's 'judicious' story of global diversity and separate development.90

For de Villiers and his associates, the case climaxed in mid-October with the testimony of Dr. Stefan Possony, a professor of sociology from the Hoover Institution at 
Stanford University. In an exchange South African propagandists' highlighted often after the judgment, the professor suggested that even if Gross's norm existed, it could only be applied to inter-state relations, not the domestic policies of individual nations.91 Dr. Possony concluded by rejecting the philosophical underpinnings of the Applicant's case:

Mankind with all its diversities has never accepted a single writ. To impose a single formula would be ideological imperialism. Given the ideals of humanity-the hopes of advance as well as the promises of human rights-but given also a manifold reality, the best principle, it seems to me, is to tailor methods or responses to specific challenges. . . As Hegel taught, reality is always reasonable in its own way. Reality can be changed, and of course it should be improved. But continuity and respect for the historical tradition remain as the unavoidable framework of human betterment.92

When South African politicians tried making this point directly to U.S. policymakers in the months before the Court's verdict, they were met by indifference and hostility. In a meeting with Assistant Secretary of State 
G. Mennen Williams, ambassador Taswell was told that the 'sincerity' of apartheid did not matter. The Republic was 'sitting on a time-bomb and heading for a racial collision.'93 Secretary of State Dean Rusk expressed similar sentiments in late 1965 in a discussion with south Africa's Minister of Foreign Affairs, Dr. Hilgard Muller. According to the American diplomat, everything turned on the fact that apartheid was alienating member-states at the United Nations. 'There may be differences between nations,' he explained, 'but the abandonment of the elementary structure would put civilization back about 500 years-there would simply be no other channel of communication on the approach to differences.' In referencing the ICJ decision, Rusk dismissed Muller's contention that South Africa would win the case, and referred suggestively to a conversation he had had with a Russian official several years earlier. 'The law is like the tongue of a wagon,' the Secretary of state explained. 'It goes in the direction in which it is pointed.' 94 This mindset was internalised in Washington by mid1966. In a National Security Council meeting on the eve of the Court's decision, Undersecretary of State George Ball opened the conversation by speculating that the judges would rule against South Africa on all counts. Although an 
armed U.N. intervention was still unfathomable, the United States could not give 'the black Africans the idea we are laying down, nor can we permit a breakdown of the International Court and the international legal system.' Debate erupted almost immediately on the utility of sanctions, with CIA Director Richard Helms and Treasury Secretary Henry Fowler suggesting that South Africa was 'one of the least vulnerable countries in the world' to such action. President Johnson, however, was less definitive. He called for the establishment of a task force-ostensibly under the guidance of Arthur Goldberg-to plot a course to 'relieve some of the pressure' of the Court's decision. In typically colloquial terms, the President explained that 'even a blind hog [could] find an acorn. $\cdot^{\prime} 95$

Few observers were distracted by such euphemisms. Watching the situation from Europe, British officials summarized, 'It is almost inconceivable that the Americans would be prepared to cast their first veto in favour of the White man in Southern Africa, let alone veto an attempt to uphold the rule of law which had been flouted by the White minority.'96 If the Applicants successfully obtained a rationale for sanctions under article 94 of the U.N. Charter, in other words, the United States would be 
obliged-in some ways even forced-to support action against South Africa. Just as Gross had envisioned, the United States would be in a political checkmate.

There was only one catch-the Court's final judgment. After seven months of deliberations and five years of litigation, this ruling came finally on 18 July 1966. With the world watching in anticipation, the ICJ unveiled a startling eight-to-seven decision.97 According to the Court's new majority, the Applicants no longer had sufficient 'legal right or interest' in the South West Africa Mandate to obtain a judgment on the merits of their case. 'Humanitarian considerations can constitute the inspirational basis for rules of law,' the Court explained, but unless given 'jurisdictional expression' and 'clothed in legal form,' it was impossible for them to 'generate legal rights and obligations.'98 The African bloc's arguments, in this regard, were 'based on considerations of an extra-legal character, the product of after-knowledge' more suited for the political realm than the legal system.99 It was not the job of the court to 'fill in the gaps' of international law.100 This decision not only reversed the logic, content, and implications of the Court's 1962 ruling; it shattered the idea that the court would act as an agent of transitional justice and teleological history. 
The ruling stunned African nationalist leaders. In the days that followed countries around the continent reacted with visceral anger. Ghana's U.N. ambassador summarized the mindset in late July, saying that the court was so 'out of tune with the tempo of [the] modern world' that African countries would never again acknowledge its 'jurisdiction' or 'authority.' 101 In testimony before U.S. Congress in August, Gross lamented that the decision had 'introduced a new element of uncertainty into international adjudication at a time when predictable and systematic legal order needs to be established.' So long as the judges were 'pro-Western and [bound] to international law which is essentially European,' Third World countries would resist and question the power of the Court.102 In commentary that foreshadowed the events of the early 1970s, the New York Times said, 'The decision on South-West Africa may appear to [African states] to confirm the growing suspicion that if Black Africa is to get help against South Africa. - it must look to the Communist bloc.' 103 In Pretoria, officials looked at the judgment with measured ebullience. In a formal statement to the international community, Prime Minister Verwoerd declared sanctimoniously that the Republic would 'not crow over [its] opponents,' even though 'impartial observers' had 
determined their claims of oppression to be 'unfounded.' The 'door of friendship' would be left open, but he warned that 'intervention in each others affairs' would benefit no one and lectured that 'world peace' would come only through economic development, not 'jealousy, interference and conflict.' 104 A secret briefing paper further elaborated on these points in early August. 'It has always been clear that the main purpose of the promoters of the South West Africa case was to obtain a Judgment in contentious proceedings, which if not complied with, could lead to an invocation of Article 94 of the Charter,' the authors explained. 'Our adversaries have consequently not succeeded in obtaining a basis for invoking Article 94 of the Charter. This is probably the most significant effect of the Judgment.' Although the political game between the African bloc and South Africa would continue at the General Assembly, the possibility of legal recourse was 'definitively shut-down.' The situation had returned to 'pre-1960 conditions.' 105

CONCLUSIONS

Scholars of international law have debated the wisdom of Gross's legal strategy for over four decades. Few have been kind.106 However, much of the criticism glosses over 
the historical exigencies facing the New York lawyer and his compatriots in the mid-1960s. The establishment of a human rights regime after World War II created a unique space for the initiatives of Third World actors in the years surrounding decolonisation. Framed in universalistic terms, the discourse of human rights rationalized the demands of the global south and created a world where European colonialism was no longer conceptually sustainable. The ICJ case was both a microcosm of this process and a turning point in its history. It was the moment when the marriage between human rights, development, and political freedom was put to the test in a court of international law. Gross's case may have marked a radical shift in legal theory, but his approach was tied intimately to a much broader movement unfolding in the years before and after decolonisation.

In the wake of the Court's decision, this story changed in dramatic ways. Anti-apartheid activism at the United Nations grew more ubiquitous but less influential in the late 1960s. Having failed to secure a victory in the legal realm, African nationalists refocused their energies on the political arena, rallying behind a series of U.N. General Assembly resolutions that superficially terminated the Mandate and renamed the territory Namibia. The 
Security Council-particularly Great Britain and the United States-refused to take action. Faced with this impasse (again), African nationalism crumbled in the late 1960s, both as a political movement and as an international discourse. Although anti-apartheid activism continued to mobilise an array of liberals, civil rights activists, and church leaders in the years to come, the clarity that marked the struggle in the years surrounding decolonisation fractured. As these trends became more obvious, liberation groups like the African National Congress (ANC) and the South West Africa People's Organization (SWAPO) turned away from their ineffectual patrons at the Organization of African Unity and moved slowly into the communist sphere of influence. By the time the Portuguese colonies finally collapsed in the mid-1970s, southern Africa was no longer the symbolic epicenter of the decolonisation struggle but merely one more battleground in the larger Cold War between the United States and the Soviet Union. 


\section{ENDNOTES}

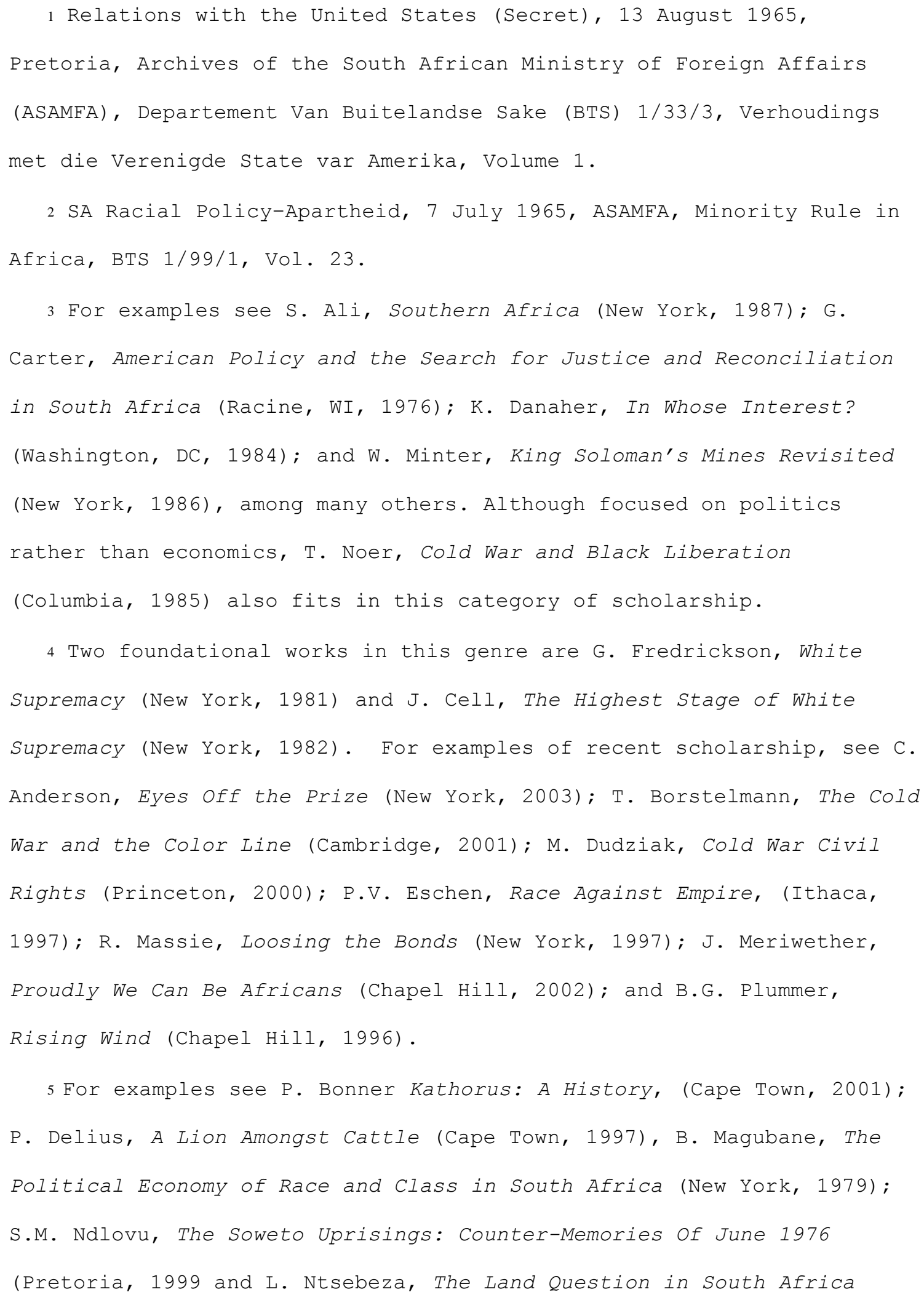


(Cape Town, 2007); R.M. Ralinala, Urban Apartheid and African Response (Cape Town, 2002).

6 M. Connelly, O.A. Westad, M. Lawrence, J. Suri, E. Manela, and M. Bradley have been particularly influential in promoting this shift toward 'international' history. However, their contributions build upon path-breaking work by scholars such as M. Hunt, A. Iriye, P. Kennedy, P.G. Lauren, and more recently T. Borstelmann, N. Cullather, and A. Rotter. For a recent historiographical overview see M. Hogan, 'The 'Next Big Thing,'' Diplomatic History 28:1 (January 2004), 1-21.

7 For a useful essay on this concept, see E. Rosenberg, 'Considering Borders,' Explaining the History of American Foreign Relations, $2^{\text {nd }}$ Edition, M. Hogan and T. Paterson, ed. (Cambridge, 2004). Many of the theoretical concepts underlying this project build on F. Cooper, Colonialism in Question (Los Angles, 2005), Tensions of Empire, F. Cooper and A.L. Stoler, ed. (Los Angles, 1997); D. Chakrabarty, Provincializing Europe (Princeton, 2001); and other historians of modern colonialism.

8 For accounts of the trial by legal scholars consult the South West Africa/Namibia Dispute, J. Dugard, ed. (Berkeley, 1973) and S. Soloman, South West Africa and the United Nations (Baltimore, 1972).

9 American foreign relations historians are only beginning to explore to concept of legitimacy, but an excellent literature exists among IR theorists. For a useful overview, see I. Hurd, After Anarchy (Princeton, 2007) and A. Wendt, Social Theory of International Politics (Cambridge, 1999).

$10 \mathrm{~K}$. Kaunda, Zambia, Independence and Beyond: Speeches of Kenneth Kaunda (London, 1966), 64. 


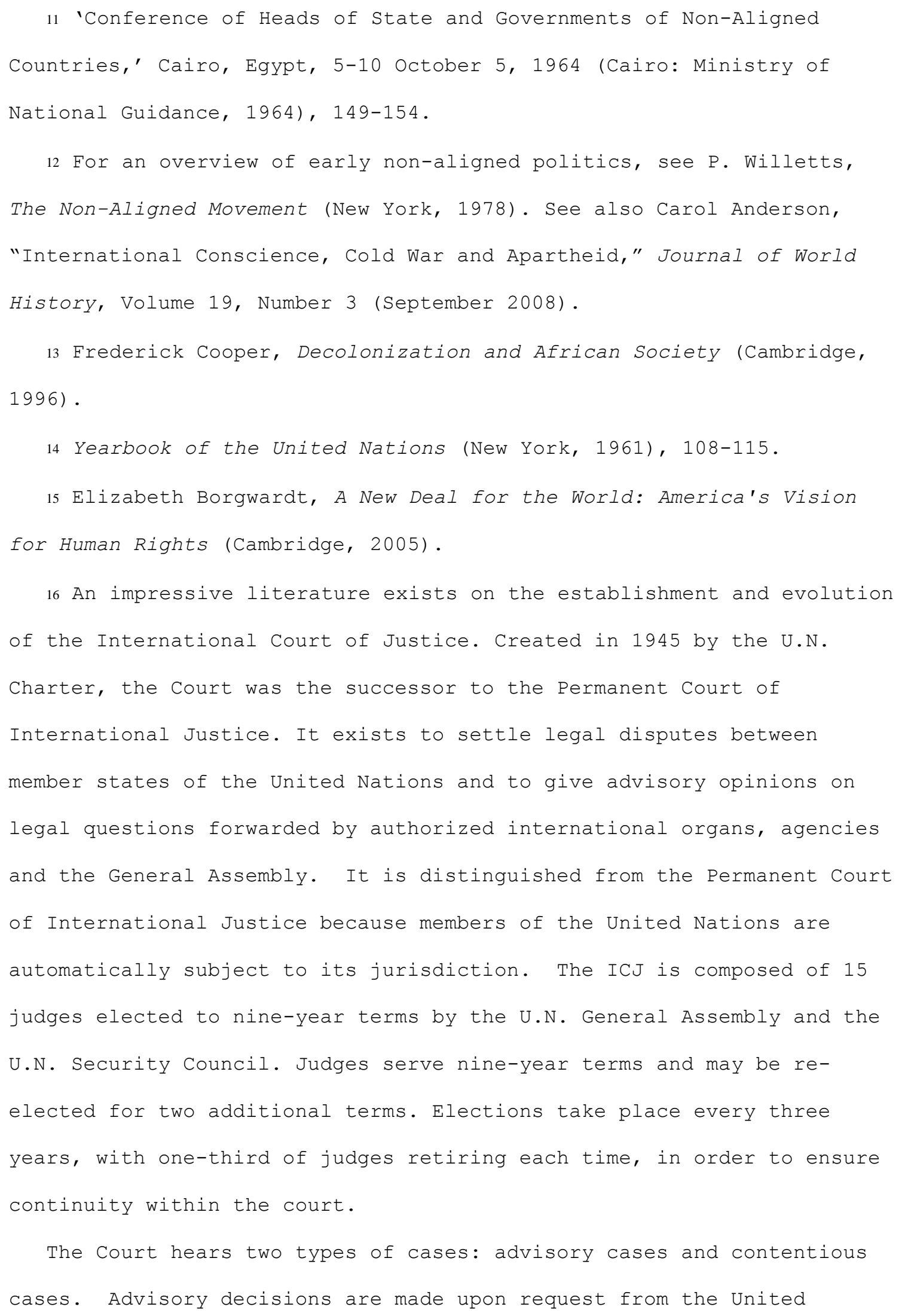


Nations. Often complex in nature, these cases require the court to independently elicit information from states and non-government organizations. Although the decisions are non-binding they are not without legal effect. The reasoning reflects the court's authoritative view on the subject, and often provides guidance (and moral authority) for governments hoping to chart a 'legitimate' course of action. Contentious hearings produce binding rulings and are enforced by the Security Council. Only governments can participate. The case begins with the submission of the Applicant's Memorial, which typically outlines the basic charges of the case. The Respondent then has an opportunity to file a Counter-Memorial, which often rebuts the Applicant's allegations.

Cases at the court often unfold in two phases. First, the Applicants must establish that the ICJ has jurisdiction to rule on the merits of the case. Because of the tenuous relationship between sovereignty and international law, this is often the most contentious phase of the trial. If the court approves its jurisdiction, the trial then proceeds to merits. During this phase, each side presents their legal rationale, offers expert witnesses, and forwards evidence to support its position. For a brief overview of the Court's organizational history, see A. Eyffinger, The International Court of Justice, 1946-1996 (Boston, 1996); N. Singh, The Role and Record of the International Court of Justice (Boston, 1989).

17 South Africa Stronger Than Ever, 12 August 1964, ASAMFA, BTS 1/99/1, SA Racial Policy - Apartheid, Vol. 25.

18 National Conference on South African Crisis and American Action, 24 March 1965, ASAMFA, BTS 1/33/3, U.S.A. Relations with S.A., Vol. 1. 


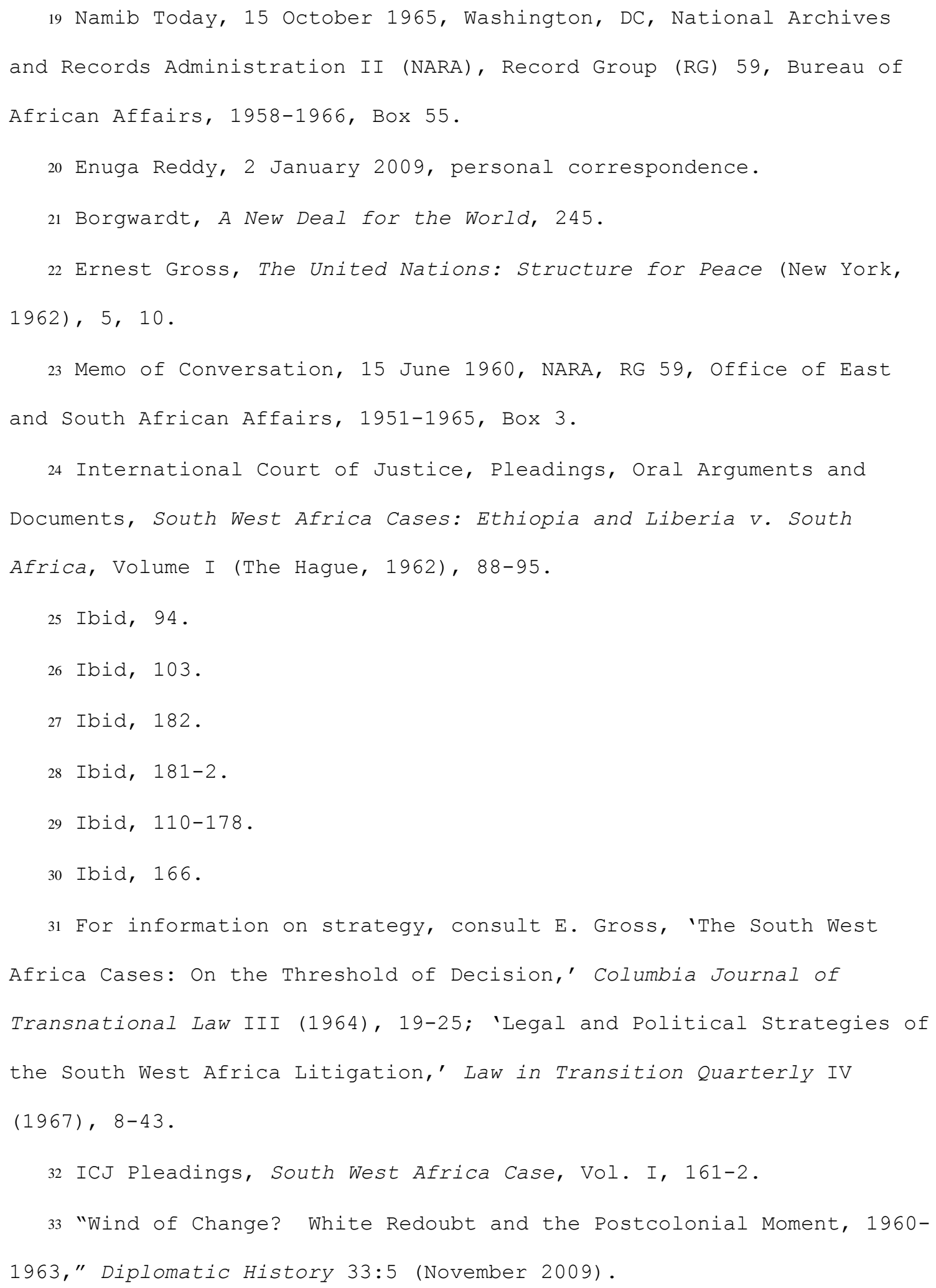


34 Legal analysis of Western Legal System, (no date), ASAMFA, BTS

1/18/15/3(1), Reactions to Judgment, (Correspondence), Vol. 11.

35 ICJ Pleadings, South West Africa Case, Vol. I, 298-360; Vol. VII, $29-156,326-8,376,382$.

36 Ibid, Vol. I, 361-71, Vol. VII, 156-99.

37 Ibid, VII, 248, (emphasis in original).

38 S. Slonim, South West Africa and the United Nations: An

International Mandate in Dispute (Baltimore, 1971), 311.

39 Analysis of ICJ Judgment on Preliminary Objections of South West Africa Case, 23 January 1962, NARA, RG 59, Office of East and South African Affairs, Box 3.

40 The Union Must Brace Up, 11 February 1960, The Cape Times, Pretoria, National Archives of South Africa (NASA), BTS 22/2/20/9, Mr. H. Macmillan's Visit: Press Cuttings, Vol. 1.

41 Sue Onslow, 'A Question of Timing: South Africa and Rhodesian UDI 1964-1965,' Cold War History 5, No. 2 (2005).

42 Quoted in A. Hepple, Verwoerd (Baltimore, 1967), 192.

43 Statement by the South African Minister of External Affairs, the Hon. Eric H. Louw, NASA, BTS 4/1/13/3, Minister of External Affairs, Vol.1 (emphasis in original).

44 Relations between South Africa and the United States: Summarized Balance-Sheet, ASAMFA, BTS 1/33/3, Verhoudings met die Verenigde state var Amerika, Vol. 1.

45 For an overview of these themes see Borstelmann, The Cold War and the Color Line; Dudziak, Cold War Civil Rights; Massie, Loosing the Bonds; and J. Meriwether, Proudly we Can Be Africans. 


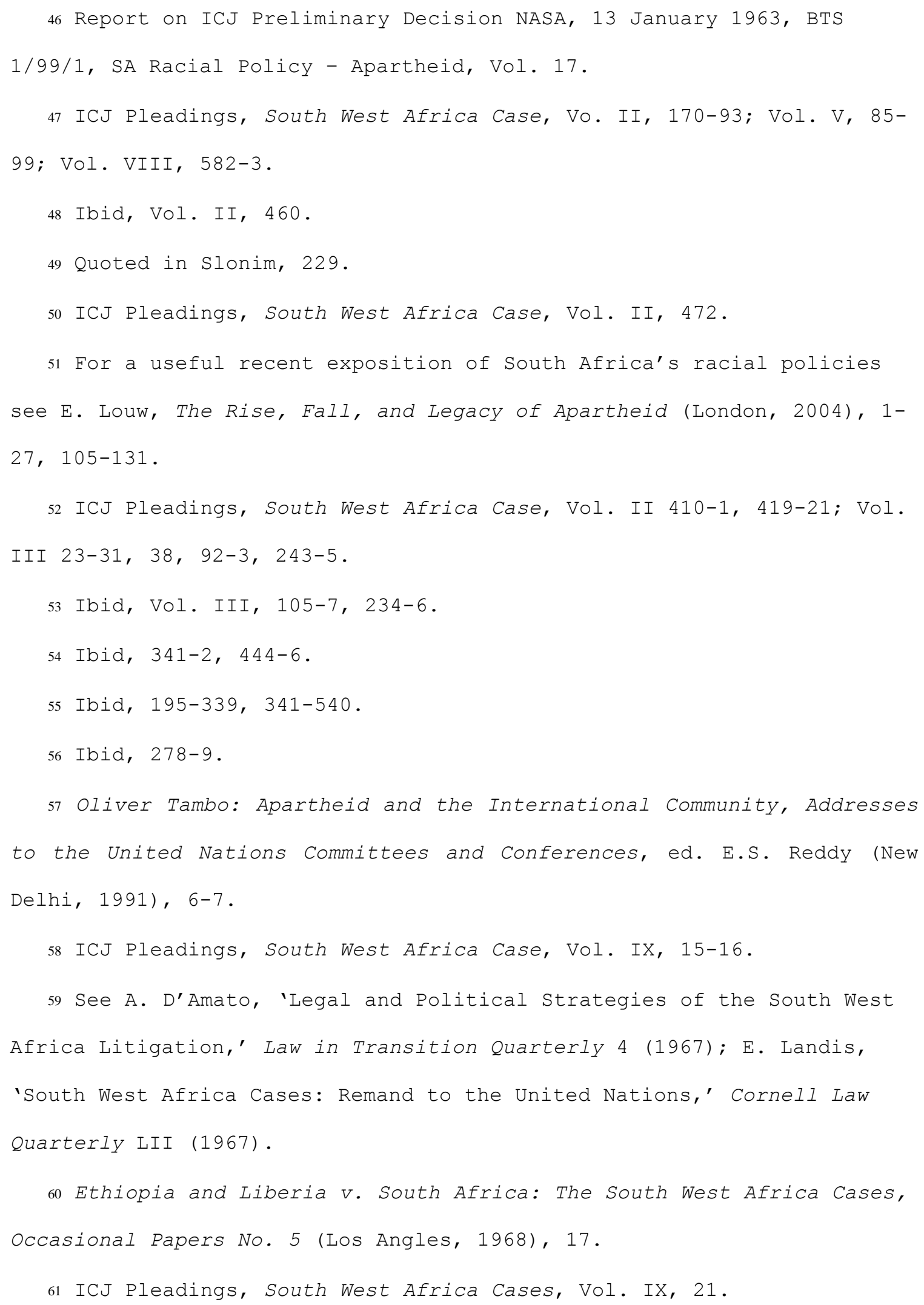




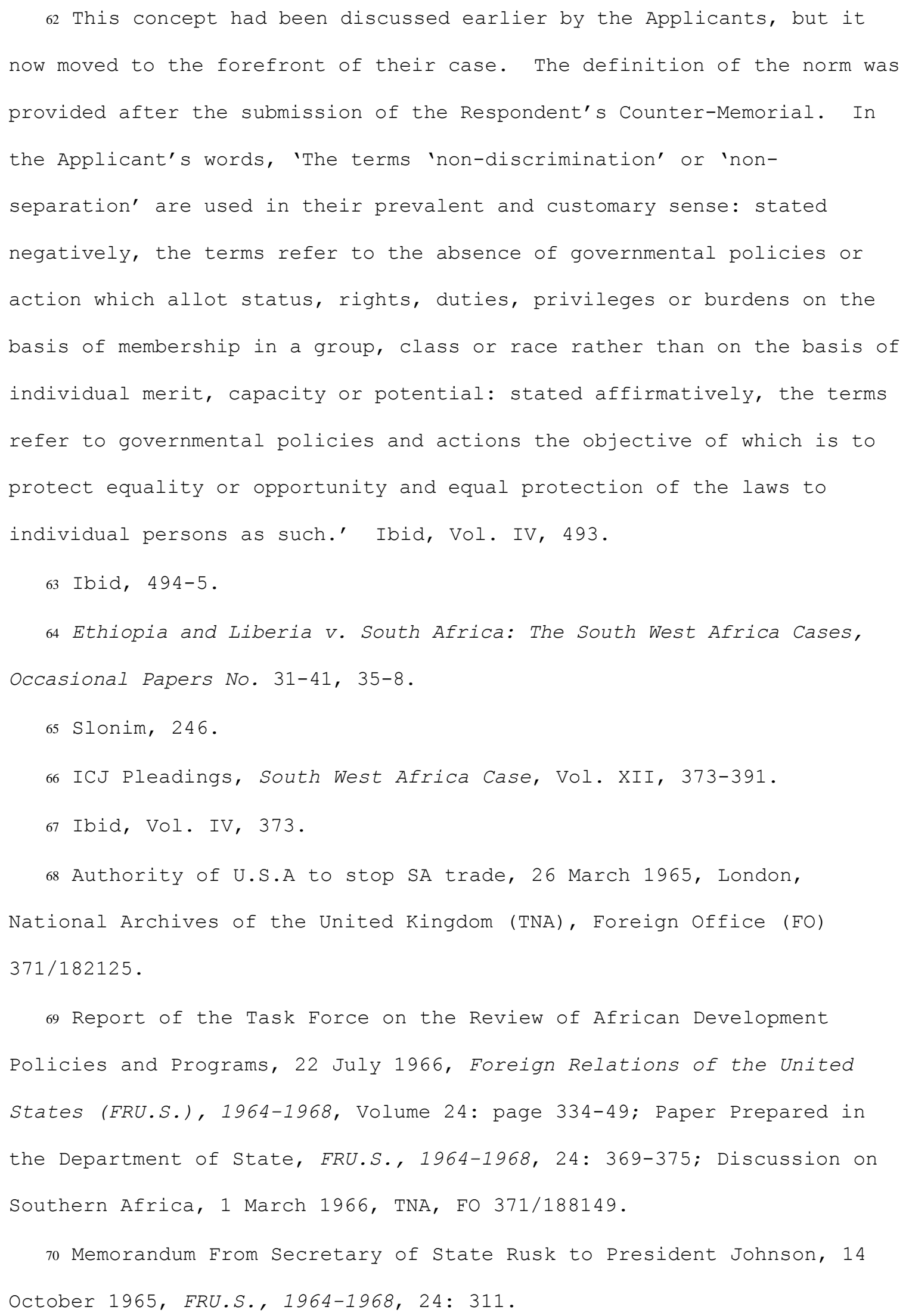

62 This concept had been discussed earlier by the Applicants, but it now moved to the forefront of their case. The definition of the norm was provided after the submission of the Respondent's Counter-Memorial. In the Applicant's words, 'The terms 'non-discrimination' or 'nonseparation' are used in their prevalent and customary sense: stated negatively, the terms refer to the absence of governmental policies or action which allot status, rights, duties, privileges or burdens on the basis of membership in a group, class or race rather than on the basis of individual merit, capacity or potential: stated affirmatively, the terms refer to governmental policies and actions the objective of which is to protect equality or opportunity and equal protection of the laws to individual persons as such.' Ibid, Vol. IV, 493.

63 Ibid, 494-5.

64 Ethiopia and Liberia v. South Africa: The South West Africa Cases, Occasional Papers No. 31-41, 35-8.

65 Slonim, 246.

66 ICJ Pleadings, South West Africa Case, Vol. XII, 373-391.

67 Ibid, Vol. IV, 373.

68 Authority of U.S.A to stop SA trade, 26 March 1965, London, National Archives of the United Kingdom (TNA), Foreign Office (FO) $371 / 182125$

69 Report of the Task Force on the Review of African Development Policies and Programs, 22 July 1966, Foreign Relations of the United States (FRU.S.), 1964-1968, Volume 24: page 334-49; Paper Prepared in the Department of State, FRU.S., 1964-1968, 24:369-375; Discussion on Southern Africa, 1 March 1966, TNA, FO 371/188149.

70 Memorandum From Secretary of State Rusk to President Johnson, 14 October 1965, FRU.S., 1964-1968, 24: 311. 
71 Memorandum From the President's Deputy Special Assistant for National Security Affairs (Komer) to President Johnson, 23 November 1965, FRU.S., 1964-1968, 24: 313.

72 Memorandum for the President, 3 May 1964, FRU.S., 1964-1968, 24: 987-988; AF Priority Issues, 3 April 1963, NARA, RG 59, Office of East and South African Affairs, Box 3; Analysis of U.S./UK approach, April 1965, NA, FO 371/182126; Telegram from Pretoria, 23 June 1966, NA, FO 371/188149; Interview by the Minister of Information, 5 August 1964, ASAMFA, BTS 1/33/3, U.S.A. Relations with S.A., Vol. 4; U.S.-U.K. Policy on Southern Africa, 8 July 1965, ASAMFA, BTS 1/33/3, U.S.A. Relations with S.A., Vol. 5a.

73 Memorandum From the Joint Chiefs of Staff to Secretary of Defense McNamara, 22 May 1964, FRU.S., 1964-1968, 24:991.

74 Memorandum From President Johnson to Secretary of State Rusk, 28 November 1965, FRU.S., 1964-1968, 24: 315.

75 National Policy Paper - South Africa (Secret), 18 January 1965, NARA, RG 59, S/P Files: Lot 72 D 139.

76 Borstelmann, Cold War and the Color Line, 172-221; Dudziak, Cold War Civil Rights, 203-249. A whole generation of scholars framed America's approach in the 1960s around its economic interests in the region. As recent scholarship reveals, the reality was far more complex. Economic issues were simply one part of a much bigger conversation within the U.S. government.

77 National Policy Paper - South Africa (Secret), 18 January 1965, NARA, RG 59, S/P Files: Lot 72 D 139.

78 Possible U.S./UK Approaches to South West Africa Problem, 24 January 1963, NARA, RG 59, Office of East and South African Affairs, Box 3; Next Steps on South West Africa, 8 February 1963, NARA, RG 59, 
Office of East and South African Affairs, Box 3; South West African Contingency Briefing Paper, 4 Mach 1963, NARA, RG 59, Office of East and South African Affairs, Box 3; The International Court of Justice on South West Africa, 22 Jun 1966, TNA, FO 371/188149.

79 National Security Action Memorandum No. 295, 24 April 1964, FRU.S., 1964-1968, 24: 985-6; 30 Status Report on NSAM No. 295, July 1964, FRU.S., 1964-1968, 24: 995-8; Status Report on NSAM No. 295, 31 July 1965, FRU.S., 1964-1968, 24: 1032-38.

80 Ibid; State Department Action to Discourage U.S. Investments in South Africa (secret), 15 February 1965, ASAMFA, BTS 1/33/3, U.S.A. Relations with S.A., Vol. 4a; Mr. Mennen Williams brief United States businessmen (secret), 29 July 1965, ASAMFA, BTS 1/33/3, U.S.A. Relations with S.A., Vol. 4 a.

81 Telegram From the Embassy in South Africa to the Department of State, 5 May 1965, FRU.S., 1964-1968, 24: 1026-7; 'Vliegdekskip: Independence, 26 July 1965, ASAMFA, BTS 1/33/3, U.S.A. Relations with S.A., Vol. 4 a.

82 Letter From Secretary of Defense McNamara to Secretary of State Rusk, 3 May 1965, FRU.S., 1964-1968, 24: 1025-6; Intelligence Report Prepared in the Central Intelligence Agency, 1 November 1966, FRU.S., $1964-1968,24: 1061$

83 Telegram From the Embassy in South Africa to the Department of State, 12 February 1964, FRU.S., 1964-1968, 24: 969-970; Telegram From the Department of State to the Embassy in South Africa, 13 April 1965 , FRU.S., 1964-1968, 24: 1025-6; Memorandum From William H. Brubeck of the National Security Council staff to the President's Special Assistant for National Security Affairs (Bundy), 18 March 1964, FRU.S., 1964-1968, 24: 974-5. 


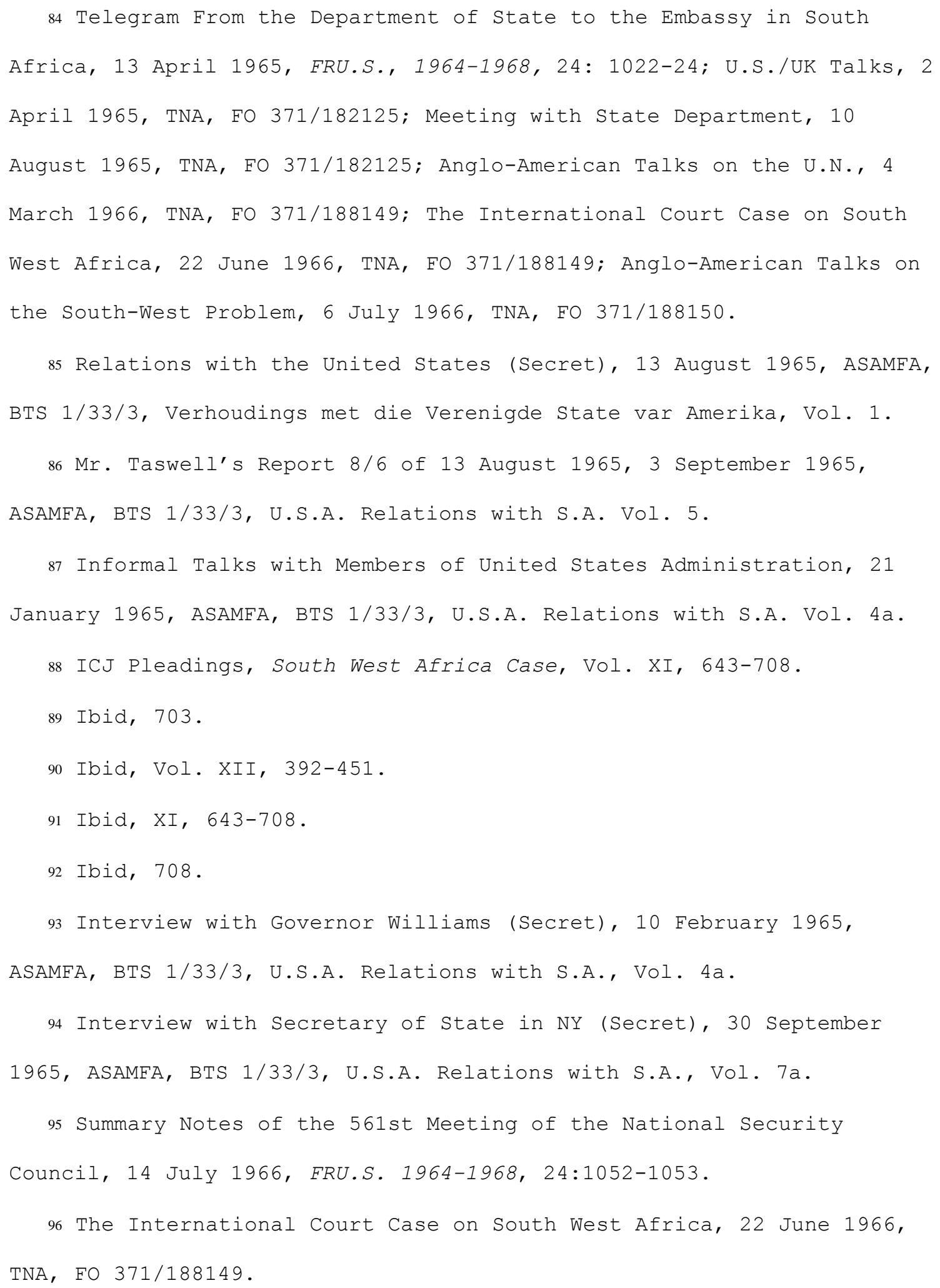


97 The story of why the Court overruled its earlier opinion is fascinating in its own right. Without delving too deeply into the internal dynamics of the court in the mid-1960s, it is worth noting that one of the judges-Bustamante y Rivero of Peru-was unable to participate in the 1966 decision because of illness. Under normal circumstances, a replacement judge would hear the case on his behalf. However, the President of the Court-Sir Percy Spender-refused to appoint such a figure because the replacement judge had been involved with non-aligned politics and lobbied to serve as the African bloc's Ad Hoc judge for the SWA case in 1960. Because this spot was left open the court was split seven-to-seven in 1966, and Spender was able to cast a tie-breaking vote. This was extremely controversial at the time. Many members of the African bloc labeled spender a racist and colonialist, and lobbied to restructure the court to better represent Third World views. Their efforts ultimately led to reforms that transformed the composition of the ICJ in the 1970s. See Interview with Expelled Judge, 1 August 1966, NARA, RG 59, Bureau of African Affairs, Box 55.

98 ICJ Judgment, South West Africa Case, 34.

99 Ibid, 49-51.

100 Ibid, 48.

101 Interview with Ghana's ambassador, 20 July 1966, ASAMFA, BTS

1/18/15/3 (62), Reactions to Judgment, Vol. 5.

102 Congress Interview with Gross, 8 August 1966, ASAMFA, BTS 1/18/15/3 (62), Reactions to Judgment, Vol. 6.

103 New York Times, 29 July 1966, Anti-climax at The Hague.

104 Statement by Prime Minister Verwoerd (Press Release), 18 July 1966, ASAMFA, BTS 1/18/15/3 (62), Reactions to Judgment, Vol. 1. 
105 Implications of ICJ Case, ASAMFA, BTS 1/18/15/3 (62), Reactions to Judgment, Vol. 9.

106 See S. Slonim, South West Africa and the United Nations (Baltimore, 1973); J. Dugard, The South West Africa/Namibia Dispute (Berkley, 1973); L. Gross, 'The United Nations and the Role of Law,' International Organization XIX (1965); N.G. Onuf, 'Professor Falk on the Quasi-Legislative Competence of the General Assembly,' American Journal of International Law LXIV (1970); L. Henkin, 'The United Nations and the Rules of Law,' Harvard International Law Journal XI $(1970)$ 